DOI: 10.46340/ephd.2021.7.3.18

\author{
Vasyl Matskiv \\ ORCID ID: https://orcid.org/0000-0002-2641-2033 \\ Odesa I.I. Mechnikov National University, Ukraine
}

\title{
AN ATTEMPT AT A NEW INTERPRETATION OF PLATO`S DIALOGUES: PROLEPTICISM (INGRESSIVISM) BY CH. H. KAHN
}

\author{
Василь Мацьків \\ Одеський національний університет ім. І. І. Мечникова, Україна

\section{СПРОБА НОВОГО ТЛУМАЧЕННЯ ДІАЛОГІВ ПЛАТОНА: ПРОЛЕПТИЗМ (ІНГРЕССИВІЗМ) Ч. КАНА}

This article is motivated by a problem of interpretation of Plato's dialogues. It is a well-known fact that new approaches emerged after the decline of the Neoplatonic interpretation of Corpus Platonicum. These are Unitarianism, Developmentalism, Esoterism, and Dramatism. At the same time, they have not offered an unequivocal answer to the "riddle of Plato's work" and have created many new problems. The emergence of any new interpretation arouses a lively interest under such circumstances. Ch. Kahn's ambitious attempt at proleptic interpretation was no exception. The purpose of this article is to outline the main features of this interpretation and offer some critical comments. Particular attention will be paid to the hermeneutic attitude of the researcher. The findings of the research show that the fundamental assumption of Unitarianism, according to which Plato had a single philosophical position from the beginning of his career and it was not radically changed during his life, is the basis of Ch. Kahn's proleptic interpretation. This position was formed early on, but it was radically new to his contemporaries. They weren't prepared for it. That is why Plato deliberately («authorial design») decided to present it gradually in the «literary project». This project provides that Plato had written the early dialogues indirectly, through many "hints», "riddles», "clues», etc., to prepare his reader for the direct presentation of the philosophical position in the «middle dialogues» (especially, in the "central books of the Republic»). But this assumption of "authorial intent» finds no support in Plato's writings. Strictly speaking, we have no significant grounds for directly attributing such the «literary project» to Plato. Thus, it is always only going to be an assumption that is introduced by the interpreter himself from outside. Moreover, even under this assumption two obvious drawbacks can be seen: 1) devaluing the early dialogues in light of the middle ones; and 2) constructing the chronology of the dialogues on subjective criteria.

Keywords: prolepsis, unitarianism, developmentalism, Plato's dialogues, Ch. H. Kahn.

Сучасний етап в дослідженні діалогів Платона починається з радикальної критики та заперечення неоплатонічного підходу в кін. XVIII - поч. XIX століття Брукером, Тідеманном і Теннеманном. Саме тоді з'явилася необхідність знову звернутися безпосередньо до текстів Платона. Таке звернення приводить багатьох вчених до виявлення в них низки суперечностей, лакун і темних місць. Зрештою, це ставить перед ними основоположне питання: у який спосіб можна працювати 3 настільки проблемними текстами ${ }^{1}$ ? У відповідь були випрацювані два основних підходи: унітаризм і девелопменталізм (або еволюиіонізм). Саме вони довгий час панували в інтерпретації діалогів Платона. Втім починаючи з середини ХХ століття, коли центр досліджень у цій царині перейшов від німецькомовного до англомовного світу, спостерігається очевидне переважання другого підходу ${ }^{2}$,

\footnotetext{
${ }^{1}$ Tigerstedt, E. N. (1974). The Decline and Fall of the Neoplatonic Interpretation of Plato: An Outline and Some Observations. Helsinki: Societas Scientiarum Fennica, 5-7, 57-67; Tigerstedt, E. N. (1977). Interpreting Plato. Stockholm: Almqvist \& Wiksell, 65-69.

${ }^{2}$ Rowe, C. (2006). Interpreting Plato. In Hugh H. Benson, ed. A companion to Plato. Chicester, 15. DOI: https://doi.org/10.1002/9780470996256.ch2.
} 
а у наш час - фактично повне домінування. Хоча класичне протистояння зійшло нанівець, занепад унітаризму та багато проблем девелопменталіму змусили шукати нові рішення, як наслідок з'явилися езотеричне та драматичне (діалогічне) тлумачення. Чи надали вони відповіді, які б прийняли більшість дослідників? Точно ні. Ба більше, загальна згода відсутня навіть в межах цих підходів. Таким чином, наразі в платонівських дослідженнях продовжуються суперечки між інтерпретаторами різних спрямувань, але значного прогресу у вирішенні «загадки Платона» немає. В такій ситуації кожна нова спроба запропонувати оригінальне тлумачення діалогів Платона привертає до себе неабияку увагу. Однією з найпомітніших за останні десятиліття стала спроба відомого дослідника античної філософії, а нині професора-емерита Пенсильванського університету, Чарльза Кана (Charles H. Kahn). Декілька десятиліть праці вилилися у низку статей та дві солідні монографії: «Plato and the Socratic Dialogue: The Philosophical Use of a Literary Form» (1996) та «Plato and the Post-Socratic Dialogue: The Return to the Philosophy of Nature» (2013).

У цій статті ми прагнемо окреслити основні риси пролептичного (інгресивного) тлумачення, запропонованого Ч. Каном, та висловити деякі критичні зауваги до нього. Здебільшого ми сконцентруємо свою увагу на методологічних питаннях, на самій герменевтичній настанові дослідника.

Уявімо на мить ситуацію, що провадимо виступ на конференції, скажімо в Пенсильванії, присвяченій проблемам тлумачення Платона, і що захищаємо наступні положення: 1) Філософія Платона зазнала радикальних змін, позаяк він довгий час був активним письменником і мислителем; 2) ці зміни відображені у трьох абсолютно різних, несумісних один з одним періодах його творчості («сократичному», де Платон йде за поглядами Сократа; «середньому», де починає розкриватися його власна філософська позиція; і «пізньому», де ця позиція радикально трансформується); 3) «сократичний» період охоплює значну частину діалогів корпусу. Якби на цій конференції був присутній Кан, зважаючи на його праці, він обов'язково мав би заперечити кожну з цих тез як сумнівну та хибну. Ба більше, запропонувати абсолютно протилежні.

Річ у тім, що первинна герменевтична настанова дослідника дещо інша, а саме: філософське тлумачення має тяжіти до того, аби за розмаїттям висловлювань та тез, запропонованих в діалогах, побачити єдність думки Платона ${ }^{1}$. Найбільш радикально це виражено в одній із статей, що передувала виданню другої книги: «...філософське тлумачення мусить шукати основоположну єдність думки між діалогами. Я вважаю за певну річ, що філософія для Платона означає пошук єдиного погляду, і тому чутливий інтерпретатор мусить починати з припущення, що у Платона $є$ такий погляд на речі» ${ }^{2}$. Таке апріорне переконання ще не обов'язково контрастує з висловленими вище положеннями, позаяк все залежить від розуміння поняття єдності. Наприклад, ми можемо вбачати єдність думки Платона в тяглості розгляду одних і тих самих проблем. Однак вже 3 декількох вступних сторінок першої книги очевидно, що Кан розуміє це принципово інакше. Його вихідне положення відображає фундаментальне переконання унітаристів про єдність філософської позиції мислителя від початку його творчості: «за літературними коливаннями праці Платона стоїть стабільний світ поглядів [Курсив авт.], визначений його прихильністю до потойбічної метафізики (otherworldly metaphysics) та до строгого сократичного морального ідеалу. Ці погляди були сформовані порівняно рано та стало підтримувалися упродовж його життя [Курсив авт.]»³. Приймаючи таку позицію, Кан декламує відхід від девелопменталізму: «я рішуче не згоден із стандартним поглядом (standard view) на Платона як автора, що захищає принципово різні філософії на різних етапах своєї кар'єри» ${ }^{4}$. Таким чином, у цьому дослідженні він намагатиметься надати нового імпульсу унітарному тлумаченню, запропонувавши свій варіант підходу. Це здійснюватиметься через постійне наголошування на опозиції до девелопменталізму, себто своєрідному відродженні класичного протистояння.

\footnotetext{
${ }^{1}$ Kahn, Ch. H. (1996). Plato and the Socratic Dialogue: The Philosophical Use of a Literary Form. Cambridge: Cambridge University Press, 36-37; Kahn, Ch. H. (2013). Plato and the Post-Socratic Dialogue: The Return to the Philosophy of Nature. Cambridge University Press, XII.

${ }^{2}$ Kahn, Ch. H. (2012). The philosophical importance of the dialogue form for Plato. In: Fink, J. L. (ed.) (2012). The development of dialectic from Plato to Aristotle. New York, 160-161. DOI: https://doi.org/10.1017/CBO9780511997969.009.

${ }^{3}$ Kahn, Ch. H. (1996). Plato and the Socratic Dialogue: The Philosophical Use of a Literary Form. Cambridge: Cambridge University Press, $X V-X V I$.

${ }^{4}$ Там само, $X I V$.
} 
Ключем до подолання «стандартного погляду» $є$ Платон як письменник-драматург. Він «великий художник» $\mathrm{i}$ «літературний талант» ${ }^{1}$, «один 3 найвеличніших драматургів», на одному щаблі 3 яким стоять лише Софокл, Евріпід і Шекспір ${ }^{2}$. Помилка «стандартного погляду» полягає у тому, що він неправильно розуміє цей бік Платона, коли розглядає його філософію. Тому Кан пропонує «прочитання текстів, яке повністю віддає належне хитрості (cunning ${ }^{3}$ ) Платона як письменника» ${ }^{4}$. Така хитрість проявляється у «зумисному» чи «свідомому» (deliberate) 5 здійсненні фактично кожного кроку при написанні діалогів. Античний мислитель створює для «вдумливого» (thoughtful), «сприйнятливого» (perceptive) та «уважного» (alert) читача ${ }^{6}$ не купу розкиданих, жодним чином непов'язаних між собою творів, а вражаюче текстове поле 3 «натяків» (hints), «прообразів» (prefigures), «загадок» (puzzle), «підказок» (clues) i т. п., за якими той, доклавши належних зусиль, побачить «вписаний в діалоги авторський задум» та «всеохопний художній план, який слід розглядати як відображення основоположної єдності філософської позиції Платона» ${ }^{7}$. Саме «гіпотеза авторського задуму», який Платон осмислено реалізовує в межах свого «літературного проєкту», витлумачена 3 позиції унітаризму, є основою пролептичного тлумачення Кана. Щоправда, як ми побачимо далі, таких проєктів-задумів у Платона було мінімум два, i їхні назви суголосні найменуванням книг американського дослідника. Почнімо короткий опис цих проєктів у порядку слідування.

Тож, перша книга охоплює аналіз 18 діалогів, починаючи з Апології та завершуючи Федром. Ці діалоги виокремлюються на підставі даних класичного стилометричного аналізу, відповідно до якого, окрім Держави та Федра, інші 16 діалогів належать до групи I‥ Однак попри фактично повну загальну згоду дослідників щодо приналежності діалогів до цієї групи, впорядкування діалогів у середині неї обертається повною незгодою, позаяк зазвичай пропонуються абсолютно протилежні лаштування ${ }^{10}$. У такий спосіб, зазначає Кан, стилометричний аналіз хоч і зумів виокремити цю групу діалогів, але він повністю безсилий вибудувати їх у правильному порядку, «тому вчений має право впорядковувати їх у будь-якій послідовності... Однак загалом впорядкування мусить підпорядковуватися літературному такту, історичному представленню, або особистому здогаду (personal hunch)» ${ }^{11}$. Послуговуючись цим правом, 3 власних мотивів, загалом окреслених вище, Кан ділить групу I на 6 етапів: 1) Апологія, Крітон; 2) Іон, Гіппій Менший; 3) Горгій, Менексен; 4) Лахет, Хармід, Евтифрон, Протагор; 5) Менон, Лісід, Евтидем; 6) Бенкет, Федон, Кратил. При цьому він продовжує наполягати, що про жодну еволюцію думки Платона не йдеться, лише про «літературну презентацію» ${ }^{12}$. Втім зазначена презентація або проєкт починають реалізовуватися не одразу.

Річ у тім, що діалоги 1-го і 2-го етапу були своєрідною пробою пера, де Платон просто приєднується до написання в жанрі «сократівських бесід», які виникають поміж учнями Сократа після його смерті. Головна особливість цього жанру полягає в тому, що в його межах твори $€$ передовсім драматичними, а Сократ - художнім персонажем ${ }^{13}$. Тому будь-які спроби створити на їхньому грунті образ історичного Сократа і його філософії від початку хибні. Так само як і спроби виокремлювати будь-який «сократичний» період у творчості Платона. Звісно, Сократ як взірець філософа, як моральний ідеал мав значний вплив на Платона ${ }^{14}$, але в самих діалогах ми можемо

\footnotetext{
${ }^{1}$ Kahn, Ch. H. (1996). Plato and the Socratic Dialogue: The Philosophical Use of a Literary Form. Cambridge: Cambridge University Press, $X V-X V I, 88 ; 126 ; 371$.

${ }^{2}$ Там само, XIII; XIV; 36; 252.

${ }^{3}$ Там само, XIV; 38; 57; 65; 182; 306.

4 Там само, 293.

${ }^{5}$ Там само, $38 ; 68 ; 179 ; 222 ; 250 ; 251 ; 339$.

${ }^{6}$ Там само, 168; 170; 178; 209.

7 Там само, 63.

${ }^{8}$ Там само, XVI; 40; 42; 58; 59; 60.

${ }^{9}$ Держава, Федр, Парменід і Теетет зазвичай належать до групи II; Coфicm, Політик, Філеб, Тімей, Крітій, Закони - до групи III. Варто зауважити, що ці групи не є абсолютними, можливо, окрім останньої. Також у групі І Кана відсутній Гіппій Більший, визнаний ним неавтентичним, див. там само, 37 (заув. 3 ).

${ }^{10}$ Thesleff, H. (2009). Studies in Platonic Chronology. In Platonic patterns: collection of studies by Holger Thesleff. Las Vegas: Parmenides Publishing, 154-163.

${ }^{11}$ Kahn, Ch. H. (1996). Plato and the Socratic Dialogue: The Philosophical Use of a Literary Form. Cambridge:

Cambridge University Press, 46-47.

12 Там само, 47-48.

${ }_{13}$ Там само, 2-3.

${ }^{14}$ Там само, 39; 71-72.
} 
шукати його філософські ідеї та історичний портрет лише в Апологї̈ ${ }^{\prime}$, яка сама собою не $є$ діалогом, та почасти в Kрітоні ${ }^{2}$. В діалогах 3-го етапу, себто Менексені, а надто Горгії, Платон починає проявляти себе як великий письменник, трансформуючи жанр «бесід із Сократом» у дещо більше ${ }^{3}$. В цей час відбувається його прощання з мріями про політичну кар'єру та переорієнтування на теоретичну, письменницьку діяльність ${ }^{4}$.

А відтак починається реалізація Платонового задуму. Кан твердить, «що коли Платон береться за написання Лахета $\ldots$ він робить це 3 перспективи значно масштабнішого задуму» ${ }^{5}$. Тобто в момент написання Лахета уже сформувалися погляди або філософський світогляд Платона, який «стало підтримуватиметься упродовж життя» і який філософ поступово розкриватиме у своєму проєкті. Він свідомо стримуватиметься у викладі своєї філософії, проявляючи «неабиякий літературний такт», позаяк тогочасне атенське суспільство було зовсім неготове до пропонованої ним радикально нової метафізики. Повне відкриття позиції реалізується в «середніх діалогах», а надто Федоні та «центральних книгах Держави» ${ }^{6}$ I лише 3 перспективи «середніх діалогів» ми можемо правильно зрозуміти низку «натяків», «замовчувань» i «загадок» в діалогах 4-го i 5-го етапу. Або послуговуючись словами самого Кана, ми мусимо «визначати значення кожного конкретного аргументу чи цілої праці, помістивши їх в більш широкий мисленнєвий світ, виражений в середніх діалогах» ${ }^{7}$. Це і $є$ сутністю пролептичного (інгресивного) тлумачення. Американський дослідник наполягатиме на цьому постійно, ось лише деякі приклади: «Насамкінець, саме ця систематична спрямованість на Державу, що пов'язує докупи всі або більшість цих діалогів [4-ий і 5-ий етапи В. М.], пропонує найбільш чітку перспективу їхньої взаємодії»; «...сім підготовчих діалогів призначені для підведення читача до поглядів, що викладені в Бенкеті, Федоні та Державі...вони можуть бути адекватно прочитані тільки 3 перспективи середніх діалогів» ${ }^{9}$; «...спосіб викладу Платона настільки приховано поступовий, що цей замисел може бути сприйнятий лише ретроспективно...ці сім діалогів можна розглядати як єдину групу, яка $є$ апоретико-пролептичним вступом до середніх діалогів» ${ }^{10}$; «Для читачів діалогів все стане зрозумілим тільки ретроспективно, коли вони досягнуть VI книги Держави...в підготовчих діалогах всі шляхи ведуть до Держави» ${ }^{11}$; «...діалоги визначення [5-ий етап - В. М.] від початку були задумані як перша стадія у всебічному вираженні тієї самої філософії, яка повно буде сформульована в середніх діалогах» ${ }^{12}$.

В першій книзі інгресивне тлумачення Кана покликане показати тяглість Платонової думки, себто відсутність радикального розриву між метафізикою, психологією та гносеологією Бенкету, Федона, Держави та більш ранніми діалогами. Іншими словами, не було ніякого «сократичного» періоду, є лише чисто платонівський період розгортання «єдиного літературного проєкту». Так, Платон довгий час був активним письменником і мислителем, але він не був флюгером,

\footnotetext{
${ }^{1}$ Це пов'язано з тим, що Апологія разюче різниться від інших діалогів. По-перше, лише вона у Платона належить до жанру традиційних судових промов; по-друге, вона зображує історичну подію (себто публічний суд), на якій сам Платон був присутній, тоді як всі інші діалоги здебільшого є вигадками і відбувалися приватно без його присутності. Втім Кан закликає бути обережними і з Апологією, визнаючи їі лише «квазіісторичним документом», в якому ми все одно не можемо провести точну лінію між історичністю та художньою вигадкою (там само, 88). Щодо інших свідчень про Сократа, то Кан їх радикально заперечує. Особливо це стосується свідчень Ксенофонта й Аристотеля, позаяк вони створювали свої образи Сократа під впливом діалогів Платона. Їхні зображення хибні, адже пройшли подвійне викривлення. Критика Аристотеля вибудовується в дусі Г. Чернісса, себто Стагірит розглядається як недобросовісний історик філософії, який тлумачив Сократа лише у світлі підступу до своєї системи; що стосується Ксенофонта, то він в 401 р. до н.е. покинув Атени, $\mathrm{i}$ не повертався туди протягом 30 років, його пам'ять про Сократа потребувала постійного живлення, яке від брав у авторів «бесід із Сократом», зосібна у Платона (там само, 75-87).

${ }^{2}$ Там само, 87-88.

3 Там само, 41.

4 Там само, 51-53; 126-127.

5 Там само, 58.

6 Там само, 68-71.

7 Там само, 59.

${ }^{8}$ Там само, 48.

9 Там само, 59-60.

10 Там само, 148-149.

11 Там само, 209.

12 Там само, 339.
} 
який змінює своє положення залежно від подуву вітру, як твердить девелопменталізм. Він мав усталені та міцні переконання фактично від початку своєї творчості, які абсолютно свідомо викладав поступово, аби підготувати широкий загал до досі незнаної і абсолютно шокуючої для тогочасних атенців філософії.

Вочевидь, вже у часі написання цієї книги Кан чітко розумів, що принаймні за своїми формальними ознаками діалоги пізнього періоду (група II і III за стилометрією) відмінні від тих, які аналізувалися тут. Дані стилометричного аналізу мали поглибити таке розуміння. Зрештою, це вилилося у підготовку підгрунтя для виокремлення другого проєкту. Таким підгрунтям став Федр, який закривав аналіз 18 діалогів цього періоду. Кан твердить, що «Федр можна розглядати як перехідний момент в творчості Платона як автора: в першій частині діалогу він прощається з високорозвиненим літературним стилем ранніх і середніх діалогів, а в другій проступає проєкт його нового способу письма, задуманий як образ усної діалектики, що практикувалася в Академії» ${ }^{1}$. Відхід від драматичного діалогу до більш дидактичного. Пояснення причин такого переходу ми не отримуємо, лише заувагу, що дихотомічна структура Федра відображає зміну Платоном своєї авдиторії, себто якщо раніше він працював на широкий загал, тепер же сконцентрувався на вузькому колі філософів-академіків. Понад це, на змістовному рівні взагалі не відбулося жодного радикального переходу «ні в концепції філософії Платона, ні в його поглядах на реальність»². Зрештою, нам пропонується оптимістичне та багатообіцяюче твердження: «В розвитку політичної теорії Платона від Держави до Законів ми можемо прослідкувати аналогічний приклад наступництва та змін в межах стабільної теоретичної основи (stable theoretical framework)» ${ }^{3}$. Таке твердження змусить серце битися швидше у будь-кого, хто коли-небудь серйозно займався Платоном, позаяк поєднати в наступництві такі різні діалоги пізнього періоду, бодай навіть на рівні політичної теорії, є завданням надскладним i, здається, ще досі ніким не вирішеним.

Сімнадцятьма роками пізніше вийде друга книга, початок якої здається продовженням ліній, які угрунтовували та завершували попередню працю. Точніше лише перші дві сторінки ії передмови. В їхніх межах наголошується, що «в шаленому розмаїтті шести діалогів» Кан продовжить шукати «Глибинну єдність інтелектуального проєкту», хоча це вже «абсолютно новий проєкт» $\mathrm{i}$ на формальному, і на тематичному рівні, позаяк він спрямований на «професійного слухача». Його сутність в тому, аби «відновити вивчення природи в межах платонівсько-елеатської філософії інтелігібельних ідей» ${ }^{4}$. Відповідно до інгресивного тлумачення, ми мали б дійти до того, аби дивитися 3 позиції Тімея та Законів, або лише Законів, і розуміти темні місця Парменіда, Теетета, Софіста, Політика та Філеба. Однак вже сам перелік цих діалогів йде у розріз із висловленою вище заувагою про «шість діалогів», позаяк їх тут сім. I дійсно, просто зазирнувши до змісту книги, ми бачимо, що Закони виключаються з розгляду як такого, адже переносяться в «Епілог». Зрештою, вони постануть як ще один автономний «незавершений проєкт», який спрямований не на професійну філософську авдиторію, а знову на широкий загал 5 . Можна було б очікувати, що попри це виключення (яке було доволі типовим для унітаристів ${ }^{6}$ ), надалі пролептичний виклад отримає своє продовження в межах інших перелічених діалогів пізнього періоду. Однак такі очікування марні. Кан прямо відмовиться від пролептизму (інгресивізму) та почасти своєї попередньої настанови: «...погляд, який я до цього описував як унітарний, либонь, більш точно може бути визначений як прогресивна розробка теоретичної основи (progressive working out of a theoretical basis) для того, що спочатку було насамперед практичною концепцією: ідеалом чесноти, змодельованої з особистості Сократа» ${ }^{7}$. Його нове тлумачення вибудовується довкола твердження про поступове розширення теорії ідей, яке у своїй основі є Аристотелевим, що призводить до появи на цьому грунті абсолютно нової хронології

\footnotetext{
${ }^{1}$ Kahn, Ch. H. (1996). Plato and the Socratic Dialogue: The Philosophical Use of a Literary Form. Cambridge: Cambridge University Press, 373.

2 Там само, 380 .

3 Там само, 387.

${ }^{4}$ Kahn, Ch. H. (2013). Plato and the Post-Socratic Dialogue: The Return to the Philosophy of Nature. Cambridge University Press, XI-XII.

5 там само, $215 ; 219$.

${ }^{6}$ Наприклад, подібний крок був здійснений знаменитим Едуардом Целлером, див. Zeller, E. (1876). Plato and the older Academy. New York, Russell \& Russell, XIII.

${ }^{7}$ Kahn, Ch. H. (2013). Plato and the Post-Socratic Dialogue: The Return to the Philosophy of Nature. Cambridge University Press, $X I V$.
} 
діалогів ${ }^{1}$. (Хронологія нова для тлумачення Кана, але ії форма класична, трирівнева.) Наводити цю хронологію, як і загалом тлумачення, немає жодного сенсу, позаяк це виходить за межі пролептизму, а отже і за межі мети цієї статті. 3 іншого боку, варто зауважити, що попри так званий «прогресивний виклад», Кан залишається вірним фундаментальному переконанню про наявність «стабільної онтології» у Платона ${ }^{2}$. Під цим він розуміє, передовсім, дуалізм мисленнєвого та чуттєвого, Буття та Становлення, який проймає фактично всі діалоги Платона ${ }^{3}$.

Досі ми окреслювали загальні риси пролептичного (інгресивного) тлумачення Кана, намагаючись передати їх якомога об’єктивніше і без висловлювання з цього приводу власних думок. Наразі ж наведемо деякі критичні зауваги.

Насамперед, варто віддати належне мужності Кана взятися за вибудовування унітарного тлумачення в час домінування девелопменталізму та нарощування сили інших підходів. Це викликає неабияке захоплення та повагу. Його ідея з «літературним проєктом» дуже глибока, позаяк після визнання більшістю дослідників результатів стилометричого аналізу, принаймні поділу на три групи, унітаризм уже не має такої розкоші, як за часів Шлейермахера чи Ріббінга, аби поставити Федр на місце першого діалогу Платона, що б чітко підтвердило наявність його філософських поглядів від початку, а вже відтак можна було б говорити про поступове розгортання його філософії в інших діалогах. Те саме стосується і радикальної відмови від важливості хронології у межах цього підходу, як це робив Шорі, особливо після визнання автентичності деяких листів. Проте, попри цікавість та проникливість такої ідеї, як і пролептизму загалом, назвати ії оригінальною вкрай складно. Річ у тім, що вже В. Йегер, аналізуючи творчість Платона в контексті виховання греків (освітній проєкт!), використовував подібний підхід ${ }^{4}$. Хай там як, це жодним чином не заперечує привнесення новизни до цього підходу американським дослідником. Головна відмінність між Йегером і Каном - концентрація на різних аспектах філософії Платона: практичному та теоретичному відповідно. Звісно, з урахуванням того, що такий поділ вкрай умовний, позаяк для самого Платона він навряд чи був актуальний.

Від самого початку у мене викликало занепокоєння найменування тлумачення Кана: інгресивне або пролептичне. Особливо це стосується другого терміна. I річ зовсім не в тому, що він переноситься з літературного аналізу античної драми, зосібна Орестеї Есхіла, проведеному Е. Лебек, на грунт аналізу філософії Платона ${ }^{5}$. Цей термін систематично відсилатиме мене до проведення аналогії 3 «протрептизмом» чи «паренитизмом» езотеристів. I така аналогія швидко виведе на спільний недолік обох тлумачень: знецінення діалогів. Безперечно, воно різного штибу. Якщо езотеристи знецінюють усі діалоги, розглядаючи їх лише як підготовку до усної «таємної доктрини», пролептичне тлумачення Кана робить те саме, тільки щодо усіх діалогів, окрім «середніх». Останні $\epsilon$ центром, до якого все рухалося і в якому все виражено прямо та повно. Таким чином, більш ранні діалоги мали свою найбільшу цінність в процесі реалізації «літературного проєкту» Платона, коли перші їхні читачі, себто сучасники-атенці, очікували нову порцію «натяків», «підказок» і «загадок», аби належно підготуватися до викладу шокуюче нової метафізики. Для нас ситуація інша: ми не потребуємо такої обережної підготовки, позаяк почасти саме метафізика Платона і досі лежить у підвалинах нашого життя, себто вона не зможе шокувати нас. Таким чином, ми можемо знехтувати ранніми діалогами, просто взявши та прочитавши Бенкет, Федон і «центральні книги» Держави, звідки отримаємо, як переконує Кан, повний виклад філософії Платона першого періоду. Але чи пропонують ці діалоги такий виклад? Звісно, мало сумнівів у тому, що «середні діалоги» являють собою більш конструктивні представлення філософської позиції Платона, ніж так звані «апоретичні», втім не менш безсумнівно, що їхня конструктивність не може претендувати на вичерпність. Зазначені діалоги не представляють струнких, ясних і несуперечливих теорій ${ }^{6}$, радше кожен з них, даючи певну відповідь, займається поглибленням

\footnotetext{
${ }^{1}$ Kahn, Ch. H. (2013). Plato and the Post-Socratic Dialogue: The Return to the Philosophy of Nature. Cambridge University Press, $X I V$.

2 Там само, $1 ; 49-51 ; 54 ; 58 ; 60 ; 86 ; 145 ; 187$.

${ }^{3}$ Там само, 147-148; 165-166; 182; 207.

${ }^{4}$ Що цікаво, в цьому контексті Кан лише раз (а загалом двічі!) цитує Йегера, вказуючи на коріння своєї «герменевтичної гіпотези», див. Kahn, Ch. Н. (1996). Plato and the Socratic Dialogue: The Philosophical Use of a Literary Form. Cambridge: Cambridge University Press, 41.

${ }^{5}$ Kahn, Ch. H. (1993). Proleptic Composition in the Republic, or Why Book I was Never a Separate Dialogue. Classical Quarterly, 85, 142. DOI: https://doi.org/10.1017/S0009838800044220.

${ }^{6}$ На ігнорування «неповноти» самих «середніх діалогів» вказував один з критиків Кана, див. Gill, Ch. (1998). Is Plato Proleptic? Polis, 15, 118. DOI: https://doi.org/10.1163/20512996-90000007
} 
самого питання, просвічуванням нових шляхів пошуку. Ба більше, на них, як і на інші діалоги, накладається проблема іронії, до слова, повністю зігнорована Каном, яка підточує беззаперечність будьякого твердження. І саме в цьому сенсі Платон справді «хитрий».

Знецінення діалогів відбувається в межах припущення про «авторський задум», яке є основою пролептизму. Це головна проблема цього тлумачення. У Кана першого тому вона буде окреслена просто як теза, належна до подолання через серію аргументів. Він зауважить: «Деякі читачі можуть не погодитися з моєю пропозицією приписати Платону авторський проєкт, який передається лише у непрямий спосіб. Яке право ми маємо приписувати Платону те, що в тексті явно не зустрічається?» ${ }^{1}$ Мушу зізнатися, що я один з таких читачів. Річ у тім, що жоден аргумент, який далі наводиться дослідником ${ }^{2}$, не спроможний подолати те, що міститься безпосередньо в текстах діалогів. Справді, коли Платон хоче сказати про якийсь «літературний проєкт», він це робить прямо, звісно, наскільки це дозволяє такий непрямий стиль викладу як діалогічна форма. Наприклад, наявність певного проєкту порівняно ясно демонструється в Політику $(284 \mathrm{~B} ; 286 \mathrm{~B})^{3}$, де є пряме посилання на Софicma i окреслення наміру написати діалог Філософ. Отже, можемо говорити про незавершений проєкт «Софicm-Політик-Філософ» або «Тімей-Крітій», позаяк у них тотожна ситуація, себто в Крітії $(106 \mathrm{~A}-\mathrm{B})^{4} \in$ пряме посилання на міркування Тімея. Чи можемо ми сказати щось подібне про «літературний проєкт» 18-ти діалогів без заступу далеко за їхні межі? Як на мене, у жодному разі, позаяк в них відсутні прямі перехресні посилання і навіть алюзії на них, подібні до тих, які $\epsilon$, наприклад, між Софістом (216 A $)^{5}$ і Теететом або Софістом $(217 \mathrm{C})^{6}$ і Парменідом. Ці діалоги створенні як незалежні та самодостатні одиниці, тому будь-яке зовнішнє накидування на них проєктності завжди зіштовхуватиметься з проблемою неможливості переконливого доведення подібного твердження. Кожен непрямий аргумент, себто «натяк», «прообраз», «імпліцитність» чи «замовчування», актуальний як частина великого задуму лише доти, доки читач сліпо слідує за автором, повністю довіряючи йому. Як тільки він не погодиться 3 тим, що певний «натяк» чи «підказка» $є$ такими, вони просто перестають існувати, а разом з ними і задум. Це те, в чому ми ніколи не маємо певності. В цьому сенсі сама історія досліджень Платона спростовує апеляцію Кана до «вдумливого», «сприйнятливого» та «уважного» читача, який побачить загальний «авторський задум», позаяк Шлейермахер, Целлер, Шорі, як і супротивники унітаризму Гатрі та Властос, були, гадаю, не менш «вдумливими» та «сприйнятливими» читачами, але такого «проєкту» не побачили. Зрештою, Кан другого тому також стане читачем з цього табору, який не погоджується зі своїм же припущенням, якраз через відсутність прямих аргументів: «Сьогодні я б сформулював свій погляд більш обережно, аби уникнути враження, що Платон ніколи не змінював свою думку або що він з самого початку знав, куди йде. Наразі я б менше покладався на поняття пролепсису, яке передбачає завчасну наявність такого плану, оскільки для цього немає прямих доказів. Хоча я все ще вірю, що ми можемо віднайти пролептичні наміри в багатьох ранніх діалогах (наприклад, в Лісідi та Евтидемі), я не розглядаю це як тезу, яка захищатиметься тут. Натомість, обмежуючи свої претензії тим, що явно виражено в тексті...» ${ }^{7}$. Однак, якщо обмежити свої «претензії» вираженим в тексті та відмовитися від пролептизму, доведеться зіштовхнутися зі значно серйознішими утрудненнями. Кан це добре розумів, тому декламував фактичну відмову від початкової герменевтичної настанови на користь «прогресивного викладу» та нової хронології, що сукупно зближує його тлумачення 3 девелопменталізмом. Хоч Кан прямо не визнаватиме такого зближення.

Насамкінець, критики Кана звертали увагу, що у першій книзі ми можемо побачити значні недоліки принципу вибудовування хронології․ До них належить довільність критеріїв. Направду,

\footnotetext{
${ }^{1}$ Kahn, Ch. H. (1996). Plato and the Socratic Dialogue: The Philosophical Use of a Literary Form. Cambridge: Cambridge University Press, 64.

${ }^{2}$ На думку Кана, Платон не дає прямого викладу своє філософії з двох основних міркувань: 1) через педагогічні переваги, які дають апорії; 2) через гострий розрив або «психологічну дистанцію» у розумінні світу між ним і натовпом, через що і була обрана «інгресивна експозиція» (там само, 66-67).

${ }^{3}$ Cooper, J. M. \& Hutchison, D. S. (ed.) (1997). Plato: Complete Works. Indianapolis: Hackett Publishing Company, $327 ; 329$.

4 там само, 1292-1293.

5 там само, 236.

${ }^{6}$ Там само, 237.

${ }^{7}$ Kahn, Ch. H. (2013). Plato and the Post-Socratic Dialogue: The Return to the Philosophy of Nature. Cambridge University Press, XIII.

${ }^{8}$ Griswold, Ch. (1999). E Pluribus Unum? On the Platonic 'Corpus'. Ancient Philosophy, 19, 361-397.
} 
ніщо не заважає нам, виходячи 3 власного «мотиву» та даних стилометрії ${ }^{1}$, поставити на будь-яке місце кожен $з$ діалогів, що належить до перших п’яти етапів у поділі Кана. Понад це, у першій книзі залишається незрозумілим, чому Кратил віднесений до 6-го етапу, на рівні з Федоном і Бенкетом. Він не виконує функції представлення позитивної доктрини у дусі останніх, і його аналіз провадиться в другій книзі у зв'язку з діалогами Teemem і Coфbicm, «прообрази» проблем яких наявні в ньомуㄹ․

Отже, в межах пролептичного тлумачення, якщо прийняти основні припущення Кана, відбувається знецінення «ранніх» діалогів, позаяк все просвітлюється та прояснюється лише в «середніх», та реалізується вибудовування хронології на довільних критеріях. А втім прийняти такі припущення американського дослідника вкрай складно через проблему неможливості прямого доведення наявності «авторського задуму», а відтак і реалізації самого «літературного проєкту». Тому в двох основних монографіях Кана про Платона ми спостерігаємо зародження та занепад пролептичного тлумачення.

\section{References:}

1. Cooper, J. M., Hutchison, D. S. (ed.) (1997). Plato: Complete Works. Indianapolis: Hackett Publishing Company. [in English].

2. Gill, Ch. (1998). Is Plato Proleptic? Polis, 15 (1-2), 113-121. DOI: https://doi.org/10.1163/20512996-90000007. [in English].

3. Griswold, Ch. (1999). E Pluribus Unum? On the Platonic 'Corpus'. Ancient Philosophy, 19 (2), 361-397. DOI: https://doi.org/10.5840/ancientphil199919233 [in English].

4. Kahn, Ch. H. (1993). Proleptic Composition in the Republic, or Why Book I was Never a Separate Dialogue. Classical Quarterly, 85, 131-142. DOI: https://doi.org/10.1017/S0009838800044220 [in English].

5. Kahn, Ch. H. (1996). Plato and the Socratic Dialogue: The Philosophical Use of a Literary Form. Cambridge: Cambridge University Press. DOI: https://doi.org/10.1017/CBO9780511585579 [in English].

6. Kahn, Ch. H. (2012). The philosophical importance of the dialogue form for Plato. In Jakob L. Fink (Ed.), The development of dialectic from Plato to Aristotle, 158-173. New York: Cambridge UP. DOI: https://doi.org/10.1017/CBO9780511997969.009_[in English].

7. Kahn, Ch. H. (2013). Plato and the Post-Socratic Dialogue: The Return to the Philosophy of Nature. Cambridge University Press. DOI: https://doi.org/10.1017/CBO9781139381734 [in English].

8. Rowe, C. (2006). Interpreting Plato. In Hugh H. Benson, ed. A companion to Plato. Chicester: Blackwell Publishing Ltd, 13-24. DOI: https://doi.org/10.1002/9780470996256.ch2 [in English].

9. Thesleff, H. (2009). Studies in Platonic Chronology. In Platonic patterns: collection of studies by Holger Thesleff (pp.). Las Vegas: Parmenides Publishing, 143-382. [in English].

10. Tigerstedt, E. N. (1974). The Decline and Fall of the Neoplatonic Interpretation of Plato: An Outline and Some Observations. Helsinki: Societas Scientiarum Fennica. [in English].

11. Tigerstedt, E. N. (1977). Interpreting Plato. Stockholm: Almqvist \& Wiksell. [in English].

12. Zeller, E. (1876). Plato and the older Academy. New York, Russell \& Russell. [in English].

\footnotetext{
${ }^{1}$ Kahn, Ch. H. (1996). Plato and the Socratic Dialogue: The Philosophical Use of a Literary Form. Cambridge: Cambridge University Press, 42-46.

${ }^{2}$ Kahn, Ch. H. (2013). Plato and the Post-Socratic Dialogue: The Return to the Philosophy of Nature. Cambridge University Press, 53-59; 78-93; 187-190 (у зв'язку з Теететом); 69-71; 83 (у зв'язку з Софістом); 133-135

(при розгляді діалектики).
} 